\title{
Exploring the American Dream in Action through Horatio Jr. Alger's Ragged Dick
}

\author{
Kpohoue Ferdinand \\ Department of English Studies, Faculty of Arts and Humanities (F.L.A.S.H.), University of Abomey- \\ Calavi, (UAC) BENIN \\ ferdinandkpo@yahoo.fr
}

\begin{abstract}
The American Dream or the dream of a land for freedom where life should be better, richer and fuller for everyone, with opportunity for every one according to his/her ability or achievement, the dream according to which all people can succeed through hard work, and that all people have the potential to live in happiness and prosperity is enshrined in the American Declaration of Independence dated July 4, 1776. This dream has been portrayed in Horatio Alger's tales where characters overcome adversity through industry, perseverance, self-reliance, and self-discipline.

This paper aims to investigate the concept of the American Dream through the lens of Horatio Alger Jr.'s fiction: Ragged Dick or, Street Life in New York with the Boot Blacks. The novel covers the hero's transformation from a ragged, homeless boy of the streets to a respectable clerk with a salary of ten dollars per week. Dick's fortunes improve because he follows advice, works hard to acquire an education, and takes advantage of every opportunity. The ubiquitous "rags to riches" legend has become a foundation of the American society; anyone can succeed and achieve material prosperity through hard work. Horatio Alger believes in the concept and shapes his characters accordingly.
\end{abstract}

Keywords: American dream, self-reliance, perseverance, rags, riches, liberty.

\section{INTRODUCTION}

The term American Dream was first used by the historian James Truslow Adams in 1931 to explain what had attracted millions of people from all nations worldwide to settle in America. The early settlers in America hoped for a life better than the one they had left behind in Europe. Their main reasons for leaving Europe were religious persecution, political oppression and poverty. They dreamt:

- the personal dream of freedom, self-fulfillment, dignity and happiness,

- the economic dream of prosperity and success, the dream of rising from poverty to fame and fortune i.e. from rags to riches,

- the social dream of equality (of opportunity) and a classless society,

- the religious dream of religious freedom in a "promised land" in which they were God's chosen people,

- the political dream of democracy.

Horatio Alger Jr. refers to the American history and reality to design his fiction plot. In fact, the concept of American Dream dates back even before the formation of the United States in 1600s, when the great migration from various European countries have started as people started coming with all kinds of hopes and aspirations for the new and largely-unexplored continent. Primarily their dreams focused on possessing land and setting up trade which would allegedly bring happiness. As the Royal governor of Virginia noted in 1774, the Americans, "for ever imagine the Lands further off are still better than those upon which they are already settled." He added that if they attained Paradise, they would move on if they heard of a better place farther west (Miller, John C 77). The divergent interpretations of the idea of American Dream also give larger scope to look into various aspects of American society and people. The indication of the idea of American Dream is itself imbibed in The Declaration of Independence where it is stated: "We hold these truths to be self-evident, that all men 
are created equal, that they are endowed by their Creator with certain unalienable rights that among these are life, liberty, and the pursuit of happiness." (Kloppenberg 147) M. G. J. de Crèvecouer in his Letters from an American Farmer enlarged the scope of the concept of American Dream:

"The American is a new man, who acts upon new principles; he must therefore entertain new ideas, and form new opinions. ... Here individuals of all nations are melted into a new race of men, whose labors and posterity will one day cause great changes in the world. . . An [immigrant] when he first arrives ... no sooner breathes our air than he forms new schemes, and embarks in designs he never would have thought of in his own country. . . . He begins to feel the effects of a sort of resurrection; hitherto he had not lived, but simply vegetated; he now feels himself a man ... Judge what an alteration there must arise in the mind and thoughts of this man; ... his heart involuntarily swells and glows; this first swell inspires him with those new thoughts which constitute an American." (de Crèvecouer 46-47)

Horatio Alger, convinced by the trueness of the American Dream, created characters who overcame hardship through industry, perseverance, self-reliance, and self-discipline. They are made to fit in the ubiquitous "rags to riches" legend in the environment where anyone could succeed and achieve material prosperity through hard work. Abraham Lincoln who had no opportunity to go to school successfully became lawyer and the $16^{\text {th }}$ President of the USA. In a speech arguing for the preservation of the Union in 1864, Lincoln stated:

"I happen temporarily to occupy this big White House. I am a living witness that anyone of your children may look to come here as my father's child has. It is in order that each of you may have through this free government which we have enjoyed, an open field and a fair chance for your industry, enterprise, and intelligence; that you may all have equal privileges in the race of life, with all its desirable human aspirations. It is for this the struggle should be maintained, that we may not lose our birthright. . . The nation is worth fighting for, to secure such an inestimable jewel." (Cullen 74).

In short, success in the USA does not depend on family background or other particular privileges because:

"This is free ground. All the way from here to the Pacific Ocean. No man has to bow. No man born to royalty. Here we judge you by what you do, not by what your father was. Here you can be something. Here's a place to build a home. . . It's the idea that we all have value, you and me . . .?” (Pillai, Rajnandini \& Susan Stites-Doe 36)

The American dream is a large concept I have decided to explore through Horatio Alger Jr.'s novel entitled: Ragged Dick or, Street Life in New York with the Boot Black. The theoretical framework can help me explain the actual meaning of Alger's technique to shape reality through his homeless characters who turn rich at the end.

\section{THEORETICAL FRAMEWORK}

The American Dream is a concept that is at the origin of the settlement of Europeans in the New World. This return to the past through fiction needs to be investigated in order to discover the intention Alger places behind this way of writing. As a matter of fact, the historical fiction novel straddles the factual and the fictive recreation of past motivations that animate historical events. It is a fictional account about the past, a story or stories told about an event perhaps fictional or real, and about people also fictional or real (Matthew J. Phillpott, 2009). According to David D. McGarry and Sarah Harriman White in their 1963 guide to historical fiction, the historical novel adds flesh to the bare bones that historians are able to uncover and by doing so provides an account that whilst not necessarily true provides a clearer indication of past events, circumstances and cultures. For Collingwood, historical events constitute the outer dimension of historical work. In fact, the Marxist literary theorist Georg Lukács is generally regarded as the most influential critic of historical fiction and his work is the basis from which later literary theorists begin their theoretical paradigms. His thesis entitled The Historical Novel (1955) saw unsurprisingly the development of historical novels in the nineteenth century as a product of social forces. Lukács argues that Sir Walter Scott (1771-1832) was the first to bring the ,specifically historical" to the novel format and is therefore to be considered the founder of the historical novel. By this, Lukács is referring to Scott's use of history as a means to understand individuals historically: 
The so-called historical novels of the seventeenth century (Scudéry, Calpranéde, etc.) are historical only as regards their purely external choice of theme and costume. Not only the psychology of the characters, but the manners depicted are entirely those of the writer"s own day. And in the most famous ,historical novel"e of the eighteenth century, Walpole"s Castle of Otranto, history is likewise treated as mere costumery: it is only the curiosities and oddities of the milieu that matter, not an artistically faithful image of a concrete historical epoch." (Lukács, p. 15)

In essence, Scottes novel is seen as the result of a new historical consciousness that had emerged in the nineteenth century; it is as much an attempt to connect with the past as it is an account of it. In Lukács words:

What matters therefore in the historical novel is not the retelling of great historical events, but the poetic awakening of the people who figured in those events. What matters is that we should reexperience the social and human motives which led men to think, feel and act just as they did in historical reality. (Lukács, p. 42)

In short, historical fiction is to, in part, educate; help readers better understand past events, societies and customs. This element of nineteenth century historical fiction is perhaps best known today through the works of Charles Dickens. The detailed, often horrific and darkly violent stories that make up the Dickens collection is testament to his work to reveal and make known the social abuses and prejudices of his own times and, at the same time, act as a warning of how governments should not act. T.S. Eliot is quite right when he said that humankind cannot bear too much reality. People do, however, create stories to come to terms with what is otherwise unbearable, unspeakable, or unimaginable. It is true to mention that fiction is not fact, but imagination which bears a part of the fact. However, the landmark is not easy to draw because they are rather complementary. A.N. Whitehead suggests in 1933 that imagination is not to be "divorced from the facts" because "it is a way of illuminating the facts. (Whitehead, 193). In other words, historical fiction helps to encourage and broaden consideration of the inner life of historical fact that informs the search for similarities and differences that exist through time in human motivation, action, and cohabitation. As portrayed in Hegi's novel, historical fiction offers a synthesis between empirical events and human explorations of beauty, goodness, nobility, and their opposites. Diverse elements - lyric (personal voice), drama (presentation of drama), epic (depiction of heroes and antiheroes often in the same person), and chronicle (description of empirical detail) - come together as students learn and explore through Hegi's example how to weave "they" and "then" and "we" and "now" into a cohabitation. To limit the theory about the use of fact and fiction, I can say that historical fiction helps to inform consideration of the inner life of historical fact in terms of offering a richer perspective on the meanings of past lives as well as the lives of those in the present, and indeed by illuminating patterns that exist in human motivation, action, and cohabitation. This examination of life, past and present, also informs agency as expressed by both individuals and social groups attempting to locate themselves in time between an imagined past and future so as to inform action with conscious intention or purpose. Horatio Alger Jr. has decided to take Ragged Dick back to the history in order to resuscitate the dream that was at the origin of the emigration of Europeans to the New World in the $17^{\text {th }}$ century. After this brief survey of the significance of the use of fiction to refer to actual past facts, I find it important to focus the concept of the American dream before coming to the fiction work for illustrative purpose.

\section{THE AMERICAN DREAM: EvOLUTION OF THE CONCEPT}

The United States has long been epitomized as a land of equal opportunity, where hard work and skill can result in personal success and fulfillment, regardless of one's station in life. While the specifics of each dream vary from person to person, the overall vitality of the American Dream has been fundamental to the nation's identity. This can be found throughout culture and history. It lies at the heart of Benjamin Franklin's common wisdom chronicled in Poor Richard's Almanack, in the words of Emma Lazurus etched onto the Statue of Liberty, the poetry of Carl Sandburg, or the soaring oratory of Dr. Martin Luther King, Jr. It can be heard in the music of Aaron Copland or jazz innovator Charlie Parker. And it can be seen across skylines from Manhattan to Chicago to San Francisco. Yet it can also be found in the most humble of places. It lies in the hopes of a single mother struggling on a minimum wage job to build a better life for herself and her children. It rests upon the unwavering belief of a teenager living on some forgotten back road that one day he or she will find fortune and fame. 
In many respects, the American Dream has been deeply rooted in the concept of a journey-the journey to a new country, the journey across generations, - and of course, the journey within one's life. It is about motion and progress, it is about optimism, and it is about finding success and fulfillment along the way. In other words, the American Dream is to achieve economic independence, especially to have a vocation and own a home in order to be happy. Instant wealth has not always been a major component of the Dream, Americans have traditionally centered their efforts on thrift and hard work. During the Colonial Period, Benjamin Franklin counseled people on the "The Way to Wealth." Poor Richard's Almanac advised on page 12 that "Early to Bed, and early to rise, makes a Man healthy, wealthy, and wise." The key to wealth was industry. Americans of the Early Republic expanded Franklin's notion of industry into a labor ideology. For many the goal was not extravagant wealth, but, rather, economic independence and the opportunity for social advancement through financial gain.

\section{The AMERICAN DREaM VieWED By The COLONISTS}

The concept of American Dream dates back even before the formation of the United States in 1600s, when the great migration from various European countries have started as people started coming with all kinds of hopes and aspirations for the new and largely unexplored continent.

Primarily their dreams focused on possessing land and setting up trade which would supposedly bring happiness. As the Royal governor of Virginia noted in 1774, the Americans, "for ever imagine the Lands further off are still better than those upon which they are already settled." He added that if they attained Paradise, they would move on if they heard of a better place farther west. (Miller, John C 77) James Truslow Adams, a prominent historian, has pointed out the all encompassing idea of the American Dream in his book Epic of America:

The American Dream is that dream of a land in which life should be better and richer and fuller for every man, with opportunity for each according to ability or achievement. It is a difficult dream for the European upper classes to interpret adequately, also too many of us ourselves have grown weary and mistrustful of it. It is not a dream of motor cars and high wages merely, but a dream of social order in which each man and each woman shall be able to attain to the fullest stature of which they are innately capable, and be recognized by others for what they are, regardless of the fortuitous circumstances of birth or position. . . The American Dream that has lured tens of millions of all nations to our shores in the past century has not been a dream of material plenty, though that has doubtlessly counted heavily. It has been a dream of being able to grow to fullest development as a man and woman, unhampered by the barriers which had slowly been erected in the older civilizations, unrepressed by social orders which had developed for the benefit of classes rather than for the simple human being of any and every class. (Adams, 214215)

In fact, during the 1600s, life in England was changing so rapidly and so drastically that men women were suffering. In the 1500s, when Spain was building its New World Empire, England was a nation of carefully tended (cultivated) farms. Three of every four Englishmen and women were tenant farmers (farmers who raised crops and lived on land belonging to another, paying as rent a share of the crops) who rented their land from the wealthy gentry or the nobility. But by 1600, England had begun to shift to commerce and industry. Textile, or cloth production was at the heart of the new economy, and wool soon became the most valuable agricultural product in England. Throughout England landowners evicted their tenant farmers, converted the tilled fields into pasture for sheep, and fenced off, or enclosed, the pastureland that had formerly been used by the tenant farmers as common property. Consequently, Farmers without farms marched together chanting, "Sheep eat men!" More than 2 million people became homeless and jobless. Many flocked to towns and cities, creating slums and massive overcrowding everywhere. Unable to find work, many of these farm people starved or turned to crime. Rich people thought of overpopulation and believed that an overseas empire was a solution to the problem. The promise of land in the colonies offered poor people an escape from poverty.

Besides poverty, there were religious tensions. In the 1600 s, the tensions between the many different Puritan sects and the Church of England were increasing. Persecution of the most active Puritan groups was common, and discrimination against both Puritans and Catholics kept the conflicts alive. By the mid-1600s, religious disagreement and intolerance would lead to civil war (1642-1660). People would seek a heaven in the new American world. Though there were some adventurers seeking greener pastures, the settlers' main motivation was land and freedom to undertake without the 
authoritarian interruption of the European kings. The American Dream has ultimately been about the manner in which lives unfold and the ability of the individual, no matter his/her origin to exert considerable control and freedom over how that process occurs. In a sense, it is about being able to live out individual lives to their fullest extent. The indication of the idea of American Dream is itself imbibed in The Declaration of Independence of 1776 where it is stated: has stressed this former aspect of the dream insisting that "We hold these Truths to be self-evident, that all Men are created equal, that they are endowed by their Creator with certain unalienable Rights, that among these are Life, Liberty, and the pursuit of Happiness". Abraham Lincoln, $16^{\text {th }}$ President of the United States of America, in a speech arguing for the preservation of the Union in 1864, stated:

I happen temporarily to occupy this big White House. I am a living witness that anyone of your children may look to come here as my father's child has. It is in order that each of you may have through this free government which we have enjoyed, an open field and a fair chance for your industry, enterprise, and intelligence; that you may all have equal privileges in the race of life, with all its desirable human aspirations. It is for this the struggle should be maintained, that we may not lose our birthright. . . . The nation is worth fighting for, to secure such an inestimable jewel. (Cullen, 74)

Here, not only opportunity is important but privilege is also added to see the evolution of the concept which reflects the realities of each epoch of the history of America. In order to stick to some aspects of the dream so as to illustrate the revolution that characterizes the dream, I undertake to go through the materialistic color which contributes to enlarge the scope of the original meaning of the American Dream. This is important simply because it appears regularly in Horatio Alger Jr.'s novel I refer to for an illustrative tool of the dream.

\section{The Materialistic ASPeCt OF THe AMerican Dream}

The Great Depression occurred in October 1929 when the New York stock market crashed resulting in the collapse of United States banks and many other financial institutions including their huge number of depositors. With receding of investment, industrial production suffered a jolt which led to falling employment and lower wages. The intensity of the Great Depression had no precedent in the history of industrial societies which has further exacerbated the skepticism of the people towards government's policies. But the Great Depression was more than an economic affair as it also made deep mark on human psychology. It affected innumerable lives by creating hardship and tension which lasted for more than a decade and continued even as the crisis itself eased. It was an event that palpably contradicted the optimistic assumptions of the later 19th century which was shared by the notion of American Dream.

Divergent interpretations of the definition of the American Dream have also invited a fair amount of criticism. Many people believe that the structure of American society beleaguered by discrimination based on class, race, ethnicity and unequal distribution of wealth itself controverts the realization of the American Dream. In fact, the dream has shifted from land owning and freedom of religion and undertaking to material goods owning. The opening of the twentieth century and particularly the economic prosperity and spreading of consumerism in American life have focused on the materialistic aspect of American Dream. Herbert Hoover, a Republican and the 31st President of the United States, in his presidential campaign slogan in 1928: "A chicken in every pot, and a car in every garage" (Ribble, 111) gave the ultimate material aspect of American Dream and it is needless to point out that the slogan had caught the attention of American voters and resulted in the thumping victory for Hoover in the presidential election.

The dream has become that of material wealth and those who happened to reach the material peak though self reliance and other opportunities are pointed to be good example of success. Andrew Carnegie and John D. Rockefeller are referred to as the richest self-made men in America. Carnegie and John D. Rockefeller were self-made men (Rockefeller's father was a confidence man, a peddler of elixirs) who stood fast by the idea that determined men would surely rise. For him, nobody should despair because he can see in each of person infinite possibilities to reach material success. As to Carnegie, there exists plenty of room at the top, and the best way to get there is to start at the bottom. In fact, One day in the late 1850s, Andrew Carnegie boarded a train in Altoona, Pennsylvania, bound for Ohio. About 25 at the time, Carnegie was working as an assistant to Tom Scott. Carnegie was in the rear car, looking out the window, when "a farmer-looking man" approached him. The farmerlooking man, who was carrying a mysterious green bag, had been told that Carnegie worked for the 
railroad, and he asked the young man for a moment of his time. Carnegie assented, and the man produced from his green bag a small model of his invention: the sleeper car. Carnegie asked him if he would come to Altoona if he sent for him, and he promised to lay the matter before Mr. Scott at once upon his return. When he arrived back in Altoona, Carnegie was as good as his word, pressing the idea on Scott, who ordered two of the sleeper cars. Carnegie telegraphed the good news to T.T Woodruff, the inventor, who was so overjoyed with the news that he offered the young man an eighth interest in his company. That was the beginning of his business involvement.

The American happiness or success in terms of material achievement appears in the American Declaration of independence in the following words: "the pursuit of happiness". Happiness here is not limited to freedom or free opportunity but a selfish and competitive run for material. He who owned property was accepted to vote at the beginning of the American democracy. Material is so prized that it determined the social status of citizens. This dream and the subsequent achievements through centuries carried the United States of America up to the roof of prosperity and has classified the US as the first world power. In a nutshell, the American Dream has become the dream to own material goods and power exponentially. The dream will keep on taking new meaning because it depends on the vision and realities of each epoch. Richard Florida in his article "The New American Dream" published in Washington Monthly gives a new perspective of American Dream:

The American Dream is no longer just about money. Better pay, a nice house, and a rising standard of living will always be attractive. But my research and others' show another factor emerging: The new American Dream is to maintain a reasonable living standard while doing work that we enjoy doing. In fact, many people are willing to trade income for work they enjoy. (www.washingtonmonthly.com)

The American Dream has become a philosophy adaptable to time and socio economic realities. My intention is not to get into the tiresome job of discussing all the different aspects of the dream, but to highlight some first degree of its evolution. This can help me explain some ideas, facts and deeds in Horatio's novel.

\section{DICK AND THE IMPLEMENTATION OF THE AMERICAN DREAM}

In Ragged Dick Alger made a homeless orphan into a hero who became the prototype for the hundreds of heroes Alger created in the next thirty years. Dick Hunter's own history is not easy to understand at the beginning. Talking about his parents to Franck, he said:

"I aint got no mother. She died when I wasn't but three years old. My father went to sea; but he went off before mother died, and nothing' was ever heard of him. I expect he got wrecked, or died at sea." "And what became of you when your mother died?" "The folks she boarded with took care of me, but they were poor, and they couldn't do much. When I was seven the woman died, and her husband went out West, and then I had to scratch for myself" (Alger, 51).

The novel covers the hero's transformation from a ragged, homeless boy of the streets to a respectable clerk with a salary of ten dollars per week. Dick's fortunes improve because he follows advice, works hard to acquire an education, and takes advantage of every opportunity. He also has the essential prerequisite to success - good character. The narrator describes Dick in the following words:

He was above doing anything mean or dishonorable. He would not steal, or cheat, or impose upon younger boys, but was frank and straight-forward, manly and self-reliant. His nature was a noble one and had saved him from all mean faults (Alger, 8).

Dick puts the welfare of others ahead of himself. He helps other homeless boys like Johnny Nolan, who doesn't have enough money for food; Henry Fosdick, who needs lodging and clothing; and Tom Wilkins and his mother, who are being evicted. Dick's frank and straight-forward manner lead people to trust him despite his shabby appearance. Such trust helps him get shoe-shine customers as well as other opportunities. For example, a gentleman asks him to guide his nephew around the city for a day because he likes Dick's honest looks. His wit and ability to laugh at himself and his circumstances also put people at ease. He tells one of his customers, "I have to pay such a big rent for my manshun up on Fifth Avenoo, that I can't afford to take less than ten cents a shine" (Alger, 5). When asked about his ragged clothes, Dick says, "This coat once belonged to General Washington [. . . . . He wore it all through the Revolution, and it got torn some, 'cause he fit so hard [. . .] if you'd like it, sir, to remember General Washington by, I'll let you have it reasonable” (Alger, 5-6). 
Dick is enterprising when it comes to business. He has "street smarts" which save him from being duped, although he has no formal education. But Dick has aspirations. He tells Frank Whitney, a patron's nephew who became a friend that he doesn't always want to be a shoe-shine boy. "I'd like to be a office boy, and learn business, and grow up 'spectable" (Alger, 40). Frank advises Dick, "A good many distinguished men have once been poor boys. There's hope for you Dick, if you'll try" (Alger, 42). Dick is willing to work hard, but Frank advises him that he must work in "the right way." Frank says, "You began in the right way when you determined never to steal, or to do anything mean or dishonorable, however strongly tempted to do so. That will make people have confidence in you when they come to know you. But, in order to succeed well, you must manage to get as good an education as you can" (Alger, 55).

Dick is also modest. He readily admits that he doesn't have the manners required in "genteel" society and never puts on airs. After Dick risks his life to save a child who has fallen in the river, he feels uncomfortable when the father praises him. The narrator writes, "Our hero was ready enough to speak on most occasions, but always felt awkward when he was praised" (Alger, 180). Because of his selfeffacing modesty, Dick benefits from the advice of young Frank Whitney and his uncle and sets out on a course of self-improvement. He strikes a bargain with Henry Fosdick, another orphan, to become his tutor. Dick says, "I can't read much more'n a pig; and my writin' looks like hens' tracks. I don't want to grow up knowin' no more'n a four-year-old boy. If you'll teach me readin' and writin' evenin's, you shall sleep in my room every night" (Alger,105). Dick studies with the same diligence and good humor he applies to his daily living. According to the narrator, Dick "had perseverance, and was not easily discouraged. He had made up his mind he must know more, and was not disposed to complain of the difficulty of the task." (Alger, 109). All this hard work pays off. When a grateful father wants to reward Dick, he learns about Dick's difficult history and recently acquired ability to write and calculate figures. The father hires Dick as a clerk, and he takes his first step towards financial success.

Coming to the concept of industry, I think it is important to refer to Benjamin Franklin to notice that the concept is not new in America. As a matter of fact, Franklin, the tenth son of a Boston candlemaker, became a world-famous scientist, a writer, an influential patriot and diplomat, and, not least, a wealthy man of business. He did reinvent himself as a means to leave behind a sordid past. In The Autobiography, Franklin offered an irresistible account of his unlikely path to prosperity, one that would thrill later generations even as they misinterpreted it. For Franklin, succeeding in business had been a means to an end. He declares:

I thence considered industry as a means of obtaining wealth and distinction which encouraged me - though I did not think that I should ever literally stand before kings, which, however, has since happened; for I have stood before five, and even had the honor of sitting down with one, the King of Denmark, to dinner. (Franklin, 100)

In The Autobiography, he lists on pages 104-105 thirteen names of virtues: Temperance, Silence, Order, Resolution, Frugality, Industry, Sincerity, Justice, Moderation, Cleanliness, Tranquility, Chastity, and Humility. For him, Industry means: "Lose no time; be always employed in something useful; cut off all unnecessary actions". (Franklin, 104) Though the concept has undergone some changes with time, industry is associated with hard work, a compulsory path toward prosperity. Dick owes his success to hard work together with other necessary qualities.

\section{DICK AND THE CONCEPT OF INDUSTRY}

Dick, in his "down and out" condition looked for success in New York, a city fabled for opportunity. $\mathrm{He}$ is an outsider, an orphan (His mother having died at three and his father gone to sea and never came back), who is searching to carve out a new identity. Ragged Dick worked to recreate himself as a clerk. He hopes to change his current economic or social condition, through education and a job. But the moral of all these stories is the ethic of hard work and perseverance. Luck helps - being at the right place at the right time, or having a helpful patron - but in the end, it is strong character and hard work that lead to success. At seven, Dick should take care of himself because the woman who takes care of him died too, her husband leaves for West as Alger stresses in chapter eight. The novel opens with Dick being woken up at seven. Normally he wakes up at six he confesses he has gone to the Old Bowery and come back home after twelve at night. Soon after, Dick is in his business with talent: "he looked sharply in the faces of all who passed, addressing each with, "Shine yer boots, sir?" (5). An hour later, he happens to get money from four customers and heads to a cheap restaurant for food. His 
method works because he masters the art of going about the business as he explains to Johnny, a less talented bootblack: "in the boot-blacking business, as well as in higher avocations, the same rule prevails, that energy and industry are rewarded, and indolence suffers. Dick was energetic and on the alert for business, but Johnny the reverse. The consequence was that Dick earned probably three times as much as the other" (Alger, 10). Johnny looks him with his mouth ajar, but Dick explains: "I keep my eyes open,--that's the way I get jobs. You're lazy, that's what's the matter." (Alger 11) He is good at his job he never learns anywhere, he gets perfection through practice and his performance is pleasing as explains the narrator: "The boots were soon polished in Dick's best style, which proved very satisfactory, our hero being a proficient in the art". (14) Dick is the embodiment of the required qualities to achieve success in the world where only the fittest can survive and achieve the dream of all. Laziness and reluctance to fit in the social and environment frame drag some dreamers out to despair or self destruction. Hard work and ambition are essential tools helpful to be closer to the American dream. In fact, 'hard' is used up to 34 times in the novel giving the very importance of this step to reach the American dream. But hard work per se is not enough opportunism plays a key role to give a new direction to his life. Anyway, poverty is not fatality in the world where everybody is granted the opportunity to glide from poverty to wealth.

\section{OPPORTUNISM}

Opportunism, in the context of the American dream, is not an inborn quality. Life in New York needs a flair for taking profit of any situation likely to provide ways of reaching some goals. Of course, needy people leave their places to make fortune in New York, a city with impossible architecture. It is a self generating environment because its architecture is intrinsically connected to the desire of its dwellers. Dick seizes the opportunity of the conversation between Franck and his uncle to make a proposition to show around New York City:

Now Dick had listened to all this conversation. Being an enterprising young man, he thought he saw a chance for a speculation, and determined to avail himself of it. Accordingly he stepped up to the two just as Frank's uncle was about leaving, and said, "I know all about the city, sir; I'll show him around, if you want me to."(Alger, 20)

In chapter six, Dick offers Frank, the rich country boy, a whirlwind tour of the city. This chapter contains so vivid description of New York that the novel can be used as a sort of tour guide. It explains the grid system of the city, shows famous edifices such as Barnum Museum and Trinity Church, and tours Central Park which was then under construction. All these details educate the reader about the economic landscape of the city. In chapter nine the following description is read:

Third Avenue is a broad street, but in the character of its houses and stores it is quite inferior to Broadway, though better than some of the avenues further east. Fifth Avenue, as most of my readers already know, is the finest street in the city, being lined with splendid private residences, occupied by the wealthier classes. (Alger, 59)

This architecture is a lure leading the needy either to turn to thief or opportunist in order to satisfy his/her irresistible greed to become rich to reality. Here Dick confesses many times that he is not a thief. He therefore seizes any opportunity at hand to ascend a social ladder. As a matter of fact, Dick offers his service. Whitney agrees to use Dick's services as a guide to Frank because Mr. Whitney (Frank's uncle) is too busy to go about this business, and they take Dick to the Astor House hotel, so he can clean up and get some second-hand clothes. Through this makeover, Dick appears to be a young gentleman:

When Dick was dressed in his new attire, with his face and hands clean, and his hair brushed, it was difficult to imagine that he was the same boy. He now looked quite handsome, and might readily have been taken for a young gentleman, except that his hands were red and grimy. "Look at yourself," said Frank, leading him before the mirror. "By gracious!" said Dick, starting back in astonishment, "that isn't me, is it?" "Don't you know yourself?" asked Frank, smiling. (Alger, 24)

Dick has undergone his very first metamorphosis. He has dropped his rags to wear some second-hand clothes. His new physical appearance betrays his intellectual capacity in terms of reading and writing. The room he rents on Mott Street at seventy-five cents a week is used to fill up the illiteracy gap. Instead of taking profit of his new living conditions alone, Dick has decided to take with him Henry Fosdick, another bootblack boy who lives with Dick and becomes his tutor. The reason behind Dick's generosity is in linked with Fosdick's capacity to train him to read and write. Dick asks his companion to train him: 
"Then I'll tell you what," said Dick; "I'll make a bargain with you.

I can't read much more'n a pig; and my writin' looks like hens' tracks. I don't want to grow up knowin' no more'n a four-year-old boy. If you'll teach me readin' and writin' evenin's, you shall sleep in my room every night. That'll be better'n door-steps or old boxes, where I've slept many a time." (Alger, 105)

The bargain has been a success and a new phase of Dick's walk towards his dream to become 'spectable' has started. As a result, in less than a year, Dick has improved a lot:

Dick had gained something more valuable than money. He had studied regularly every evening, and his improvement had been marvellous. He could now read well, write a fair hand, and had studied arithmetic as far as Interest. Besides this he had obtained some knowledge of grammar and geography. (Alger, 135)

This step has prepared the ground for a higher achievement of Dick's dream. A new opportunity could help him to reach an upper step towards his goal. In fact, One Wednesday afternoon, Dick and Henry Fosdick are taking the South Ferry when a six years old boy has fallen into the river. Dick, who is a good swimmer, readily has jumped in to save the child who is about to go under for the third time. Dick is able to save the child, and the father has promised to reward him admirably. The next morning Dick has gone to the offices of Mr. Rockwell, the father, to reclaim his clothing. There Mr. Rockwell asked Dick about his past and future prospects and hired him as a clerk at a salary of $\$ 10$ per week. Dick has come to the top of the mountain and has abandoned his bootblack activities. Alger has taken profit of his main character to jump into the very system of the psychology that paved the way to the colonization of the New World. Opportunism is a reality of the American dream and its implementation has paid over generations.

\section{CONCLUSION}

Horatio Alger Jr. believes in the American Dream. In Ragged Dick he has taken Dick to revisit the different characteristics of the dream. Dick, an orphan, is obliged to take care of himself at seven. In New York he has become a bootblack together with some other street boys. But with his cleverness, honesty, hard work, self-reliance and his capacity to take profit of opportunities have helped him to go through positive changes up to the rank of a clerk with a salary of $\$ 10$ per week. He is a self-made person like so many others in the American history. From the street and rags, Dick has worked to change his physical appearance and in nine months he has got rid of his illiteracy which could mar his progress toward the fulfillment of his dream. He has become a 'spectable' person and has changed his name to be called Dick Hunter. In short, America is a world of opportunity for anyone in a position to work hard with the objective to reach success whatever his background may be. People have equal chance in the society, nobody is naturally or hereditary luckier than anybody. The challenge is open to everybody. In the midst of industrialization following the Civil War, many Americans experienced profound hardship in the changing economic landscape. They found solace in the tales of Horatio Alger, whose characters overcame adversity through industry, perseverance, self-reliance, and selfdiscipline. The ubiquitous "rags to riches" legend became a cornerstone of American society; anyone could succeed and achieve wealth if they worked hard. The American dream is shaped positively by Alger Jr., but it may turn into nightmare, disappointment or failure in many cases.

\section{REFERENCES}

[1] Adams (Truslow James), The Epic of America, Boston, Little, Brown, and Company, 1931.

[2] ALDEN (John R.), MAGENIS (Alice), A History of The United States, New York, American Book Company, 1962.

[3] ARMENTO (Beverly J.); NASH (Gary B.); SALTER (Christopher L.); WIXSON (Karen K.), America Will Be, Boston, Houghton Mifflin Company, 1991.

[4] BAILEY (Bernadine), Abraham Lincoln, Man of Courage, Boston, Houghton Mifflin Company, 1960.

[5] BAILEY (Thomas A), The American Spirit: United States History As Seen by Contemporaries, Volume I, Boston D.C., Health And Company, 1963.

[6] BAILEY (Thomas A), The American Spirit: United States History As Seen by Contemporaries, Volume II, Boston D.C., Health And Company, 1963. 
[7] BARCK (Oscar Theodore Jr.; Blake, Nelson Manfred), Since 1900, New York, The Macmillan Company, 1952.

[8] BERKIN (Carol; Wood Leonard), Land of Promise, A History of the United States, 2nd Ed. Illinois, Scott Foresman and Company, 1987.

[9] Franklin (Benjamin) The Autobiography of Benjamin Franklin, New York, Spencer Press, 1936.

[10] Hector. J. St. John de Crèvecœur. Letters from an American Farmer. London : Printed for T. Davies, 1782.

[11] Horatio (Alger Jr.), Fame and Fortune, Boston, Loring publisher, 1868.

[12] Horatio (Alger Jr.), Ragged Dick or, Street Life in New York with the Boot Blacks, Boston, Loring publisher, 1868.

[13] HUBERMAN (Leo), We, The People, New York, Harper \& Brothers Publishers, 1947.

[14] JAMESON (J. Franklin), The American Revolution Considered as a Social Movement, 1926, New Jersey, Princeton University Press, 1967.

[15] JORDAN (D. Winthrop), GREENBLATT (Miriam) and BOWES (S. John), The Americans, The History of a People and a Nation, New York, McDougal, Little \& Company, 1988.

[16] LAXALT (Robert), Sweet Promised Land, New York, Harper \& Brothers Publishers, 1957.

[17] Lukács (Georg), The Historical Novel, Boston, Beacon Press, 1955.

[18] MILLER (James), The Makings of America: The United States and the World, volume I: to 1865, Lexington, D.C. Health and Company, 1993.

[19] Miller (John C), Origins of the American Revolution, USA, Stanford University Press, 1959.

[20] NASH (B. Gary), American Odyssey, The United States in the Twentieth Century, New York, Glencoe McGraw-Hill Company, 1999.

[21] PATRICK (John); BERKIN (Carol), History of the American Nation, New York, Macmillan Publishing Company, 1984.

[22] WHALEN (Frank D.), PARKHILL (Wilson), Founders of our United States, New York, Noble and Noble, Publishers, Inc., 1946.

[23] WINTHROP (D. Jordan), MIRIAM (Greenblatt), JOHN (S. Bowes), The Americans: The History of a People and a Nation, New York, McDougal, Littell \& Company, 1988.

[24] ZINN (Howard), A People's History of the United States, New York, Harper \& Row, Publishers, 1980.

\section{AUTHOR's BIOGRAPHY}

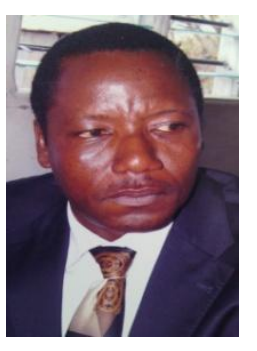

Ferdinand KPOHOUE, holds a Doctorate degree in American Studies since 2012. $\mathrm{He}$ is a Senior Lecturer of American Literature and Civilization. He is currently the Head of Department of English Studies, Faculty of Arts and Humanities (F.L.A.S.H.) of the University of Abomey-Calavi (UAC). Dr. Kpohoue is a true bilingual scholar, conversant and fluent in English and French with his five previous articles published in those two languages in the field of American Literature and Civilization with special focus on Slavery and African-Americans' history, evolution and literature both in national and international journals. 